sciendo Zagreb International Review of Economics \& Business, Vol. 23, Special Conference Issue, pp. 91-104, 2020 (C) 2020 Faculty of Economics and Business, University of Zagreb and De Gruyter Open

All rights reserved. Printed in Croatia

ISSN 1331-5609; UDC: $33+65$

DOI: $10.2478 /$ zireb-2020-0025

CONFERENCE PAPER

\title{
The R\&D Spillovers, Innovation and Knowledge-based Economy
}

\author{
Olga Miroshnychenko*
}

\begin{abstract}
The R\&D processes generate knowledge and enhance innovation activity. Knowledge and ideas developed by one agent may spill over to and can be used for economic and acquired by other agents. The results of these processes are known as the $R \& D$ spillover effects. Factors, that have influence on innovation diffusion, and determine the place of the $R \& D$ spillovers in knowledge-based economy have been investigated in the article. The definition and types of knowledge have been examined. The relationship between the $R \& D$ cooperation, different types of knowledge, knowledge spillovers and innovation have been traced. The main objectives of the paper are to consider the concept of the $R \& D$ spillovers and connection between different types of knowledge and the $R \& D$ spillover effects. Systematic comparative analysis, synthesis and generalization of the scientific literature have been carried out in order to create the theoretical background of the research of the $R \& D$ spillovers and innovation. The qualitative research methods have been employed to investigate relationship between the $R \& D$ spillovers and different types of knowledge. The $R \& D$ positive effect of spillovers on innovation activity, promotion of cooperation between different agents (individuals, business entities, organizations, and countries), spreadability and access to knowledge on nonprofit basis and enhancement of innovation diffusion have been identified.
\end{abstract}

Keywords: innovations; knowledge; tacit and explicit knowledge; the R\&D spillovers; the R\&D spillover effects

JEL Classification: O31, R11

* Olga Miroshnychenko is Associate Professor of Business Economics Department at Taras Shevchenko National University of Kyiv, Ukraine, e-mail: olgamir.ua@gmail.com. ORCID ID: https:/orcid. org/0000-0003-3822-4803 


\section{Introduction}

The emergence of the knowledge-based economy as a socio-economic phenomenon is due to the existence of external knowledge effects as an important source of innovation development.

The level of innovation activity depends on the exchange of ideas, information, and knowledge among individuals, between companies, organizations and countries. There are positive externalities from knowledge exchange at different level (individual level, company level, global level) that will be delivered through innovation. Innovation helps to transform new ideas into new method of production, new source of supply, new market or application, new method of organizing your company or industry (Schumpeter, J., 1934). The more innovation activity the newer knowledge will be acquired and the more R\&D spillovers can be spread. Incoming the R\&D spillovers affect the level of innovation development of the company and have the connection with appropriability, that effects the ability of the company to get returns from innovation (Cassiman, B., Veugelers, R., 2002).

The $R \& D$ processes play crucial role in providing long-run productivity, economic growth and competitiveness. The R\&D activity of the company increases its innovation performance, may extent impact on the profitability, innovation development and the R\&D expenditures of other companies by the R\&D spillover effects. The R\&D spillovers benefits may be arisen in the process of innovation activity, enhance longrun growth in economy, produce an additional incentive for innovation development.

The existence of the R\&D spillovers is related to the $R \& D$ expenditures and may increase the incentive for company to invest in $R \& D$ if other companies' $R \& D$ is complementary, increasing company's own R\&D effectiveness. However, existence of the R\&D spillovers of other companies and public institutions may have negative effects on companies' own R\&D expenditure and reduce their level (Bakhtiari, S., Breuning, R., 2017).

The R\&D spillovers have connection with endogenous growth theory, which explains economic growth through endogenous forces (that are related to human capital, knowledge, innovation) rather the external forces. The theory of endogenous growth focuses on positive R\&D spillover effects of endogenous forces (Romer, P.M., 1986). The spillover effects facilitate the economic growth in an indirect way - knowledge created one economic agent may contribute to the productivity growth of the other economic agents in various geographic areas and may reduce duplication of the R\&D efforts.

The purpose of the article is to consider key characteristics of the type and forms of knowledge, explain their connection with the R\&D spillovers and develop the classification of the R\&D spillover effects. The structure of the article is following: the relevant literature overview related to the topic of the research has been summarized at the second stage, the methodology has been elaborated at the third stage, findings of the results have been provided at the four-six stage. Conclusions complete the article. 


\section{Literature Overview}

The concept of knowledge management has been considered in the extend number of research: P.F. Drucker (1993); T.H. Davenport and L. Prusak (1998); A. Gaponenko; P.R. Gamble and J. Blackwell (2001); T. Orlova (2008), J.M. Wellman (2009); H. Gupta (2011); E. Hajric (2018). E. Bolisani and C. Bratianu (2018). Features of the formation of explicit and tacit knowledge have been presented in the scientific papers of M. Polani (1966). The dynamic theory of knowledge creation and the concept of tacit knowledge management have been examined in the research conducted by I. Nonaka (1994), I. Nonaka and H. Takeuchi (1995, 1996), P.R. Nelson and S. Winter (1982); M.D. Cohen et al. (1996). The category "knowledge spillovers" has been characterized in the scientific articles of D. Grossman and E. Helpman (1991); A.B. Jaffe (1998); D.B. Audretsch and M. Keilbach (2007); Z. Atkochiuniene (2019) and O. Miroshnychenko (2019,2020). Types of the R\&D spillovers and spillover effects have been the object of the scientific research of Z. Grilichez (1992), S. Breschi and F. Lissoni (2001), D. Tsyplakova (2010), D. Meissner (2012). Spillover effects of information and communication technologies in higher education have been analyzed in scientific paper conducted by E. Ogurtsova et al. (2019). Different types of knowledge spillover effects have been examined in the research of A. Marshall (1920); K.J. Arrow (1962); P.M. Romer (1986); Z. Griliches (1992); U. Kaiser (2002); D. Czarnitzki and K. Kornelius (2007); A. Kandler and J. Steele (2009); D.A. Tsyplakova (2010); D. Meissner (2012); J. Medhurst et al. (2014); V. Ramadani et al. (2017). The differences between the innovative and absorption potential of the knowledge recipient have been presented in the scientific works of D. Meissner (2012); V. Cohen and D. Levintal (1991), D. Leahy and J. Neari (2007). The impact of the R\&D spillovers and innovation on firm-performance of Japanese companies have been considered in the works of A. Goto and K. Suzuki (1981); Swiss companies - N. Harabi (1997); Belgium business entities - B. Cassiman and R. Veugelers (2002); Australian industries - S. Bakhtiari and R. Breuning (2017); the Balkans countries - V. Ramadani et al. (2017). Geographical knowledge spillovers and regional growth have been the object of the survey of T. Döring and J. Schnellenbach (2006).

\section{Methods}

The research was carried out based on the results of critical, comparative analysis and synthesis of the research works in the area of the R\&D spillovers, innovation and knowledge-based economy. To consider the main differences between knowledge and more traditional resources, to explain the nature of the R\&D spillovers the systematic comparative analysis, synthesis and generalization have been used. In order to determine connection between tacit and explicit knowledge, and the R\&D spill- 
overs the inductive method has been employed. To identify types of the R\&D spillover effects and to build classification of knowledge spillover effects the comparative, systematic analysis and interpretation have been used. For formulating conclusions of the research, the synthesis analyses have been used.

\section{Connection between Knowledge and R\&D Spillovers}

Knowledge creates value of the company and increase its competitiveness in knowledge-based economy. In the information, postindustrial society knowledge is the most important "factor of production", rather than capital, land, labour (Drucker, P.F., 1993). Z. Griliches (1992) pointed out, that investments in knowledge have a high probability to spill over for commercialization by other business entities, that do not compensate the full cost of acquiring and implementing that knowledge in contrast to investments in traditional resources. Thus, the main difference between knowledge and the more traditional resources is the high propensity of knowledge to spill over (Audretsch, D.B., Keilbach, M., 2007).

The term "knowledge" as explained by various authors is illustrated in the table below (see Table 1).

\section{Table 1: Definitions of Knowledge}

\begin{tabular}{|l|l|}
\hline \multicolumn{1}{|c|}{ Authors } & \multicolumn{1}{c|}{ Definitions } \\
\hline $\begin{array}{l}\text { Bolisani, E. } \\
\text { Bratianu, C. } \\
(2018)\end{array}$ & $\begin{array}{l}\text { "Knowledge is justified true belief and is shown to have the limitations given by the } \\
\text { justification condition and the truth nature." }\end{array}$ \\
\hline $\begin{array}{l}\text { Gupta, H. (2011), } \\
\text { p. 235-236 }\end{array}$ & $\begin{array}{l}\text { "Knowledge is a set of information which provides capability to understand different } \\
\text { situation, enables to anticipate implications and judge their affects, suggest ways or clues } \\
\text { to handles the situation... Knowledge is a closely link to doing and implies know-how and } \\
\text { understanding." }\end{array}$ \\
\hline $\begin{array}{l}\text { Davenport, T.H., } \\
\text { Prusak, L. (1998) }\end{array}$ & $\begin{array}{l}\text { "Knowledge is neither data nor information, though it is related to both, and the differences } \\
\text { between these terms are often a matter of degree... Knowledge is a fluid mix of framed } \\
\text { experience, values, contextual information, and expert insight that provides a framework for } \\
\text { evaluating and incorporating new experiences and information. It originates and is applied in } \\
\text { the minds of knowers. In organizations, it often becomes embedded not only in documents } \\
\text { or repositories but also in organizational routines, processes, practices, and norms." }\end{array}$ \\
\hline $\begin{array}{l}\text { Nonaka, I., } \\
\text { Takeuchi, H. } \\
(1995), \text { p. 87 }\end{array}$ & \begin{tabular}{l} 
Knowledge is that of "justified true belief." \\
\hline Plato
\end{tabular} \\
\hline
\end{tabular}

Source: compiled by the author

The nature of the R\&D spillovers depends on the type and forms of knowledge. K.J. Arrow (1962) pointed out, that knowledge is characterized by two fundamental conditions: the first one involves non-excludability, and the second one is non-ex- 
haustibility (the same knowledge can be used in different ways; use of ideas by one entity does not exclude others from using that same knowledge) (Audretsch, D.B., Keilbach, M., 2007). Knowledge is non-rival (knowledge can be used in various applications and different locations at the same time) and non-excludable (the authors of an idea may have difficulty getting remuneration from business entity in many cases) (Grossman, G., Helpman, E., 1991).

In 1966, the British philosopher and mathematician M. Polanyi (1966) proposed the concept of dividing knowledge into explicit and tacit. Explicit knowledge is codified knowledge that is expressed as words and numbers and transferred in a formalized manner (documents, articles, books, etc.). Tacit knowledge is hardly formalizable knowledge that can only exist along with its owner - a person or a group of persons. It is difficult to transfer tacit knowledge from one subject to another. This type of knowledge is formed on the basis of individual actions and experience. Initially, all inventions and new ideas are presented as tacit knowledge that is possessed by an individual or a group of people. Tacit knowledge is the most valuable source of knowledge, and has a high probability to lead to the breakthroughs in the company (Wellman, J.M., 2009).

The holders of both explicit and tacit knowledge can be either a specific individual or an organization or company. Consequently, there is tacit group knowledge that lays the foundation for the collective reaction and internal interaction models. The term "routine" is used to refer to tacit group knowledge. The term "routine" was introduced by P.R. Nelson and S. Winter (1982) as "regular and predictable behavioral patterns of firms" (Nelson, P.R., Winter, S., 1982, p. 14). According to P.R. Nelson and S. Winter a routine "may refer to a repetitive pattern of activity in an entire organization, to an individual skill, or, as an adjective, to the smooth uneventful effectiveness of such an organizational or individual performance" (Nelson, P.R., Winter, S., 1982, p. 97). The scientists of the Santa Fee Institute defined routines as "an executable capability for repeated performance in some context that has been learned by an organization in response to selective pressures" (Cohen, M.D. et al., 1996, p. 684). Routines are seen as patterned actions and normal behavioral patterns (common practices, certain work styles, and informal rules) - something that happens automatically, without instructions and options. Routines cannot be codified, do not exist in isolation, and shape interdependence.

The boundaries between explicit and tacit knowledge are relative, since some knowledge may be tacit for some members of an organization or company and explicit for others. Moreover, it is impossible to state categorically that some knowledge is tacit to a certain degree (Gaponenko, A., Orlova, T., 2008).

The notion of tacit knowledge was popularized by I. Nonaka (1994), the Japanese professor and the founder of the Institute of Knowledge. I. Nonaka and H. Takeuchi (1995) developed the SECI model (Socialization, Externalization, Combination, Internalization) used to create new knowledge in an organization and explain the 
interaction of explicit and tacit knowledge. The spiral of knowledge consists of four processes of their transformation (Nonaka, I., Takeuchi, H., 1995):

1. Socialization is a non-verbal transfer of tacit knowledge from one member of an organization to another through observation, imitation, and practice. Socialization promotes the dissemination of knowledge and the creation of tacit knowledge. An example would be the dissemination of intellectual models and technical competence and the situation where one employee watches another employee performing a task.

2. Externalization is the process of articulating tacit knowledge into explicit concepts thanks to the nonstandard use of language, various metaphors, and analogies. When conceptualizing an image, we express its essence mostly in words. The process of writing is an act of transforming tacit knowledge into articulable knowledge. Expressions are often perceived inadequately, as they can be distorted or partially communicated to readers. Nevertheless, such discrepancies and gaps between images and expressions help promote "reflection" and interaction between individuals.

3. Combination is the transfer of explicit knowledge from one employee to another by using books, newspapers, lectures, computer technology, etc. Individuals share and combine knowledge through such media as correspondence, meetings, phone conversations, and computerized communication networks. Reconfiguring current information by sorting, adding, combining, and categorizing explicit knowledge can generate new knowledge. As an example, it would be the creation of knowledge in the process of formal education received at educational institutions.

4. Internalization is the transformation of explicit knowledge into tacit knowledge (in a masked form, e.g., through the practical implementation of an activity). Internalization is closely related to the method of "learning by doing". When experiences through socialization, externalization, and combination are internalized into individuals' tacit knowledge bases in the form of shared mental models or technical know-how, they become valuable assets. Transforming explicit knowledge into tacit knowledge can be facilitated if it is presented in words, i.e., as diagrams, instructions, etc.

It is worth noting, that tacit knowledge can be exchanged only at the individual level, while explicit knowledge can be exchanged both at the individual level, at the level of companies and organizations, and at the global level. For instance, explicit knowledge is exchanged at the global level through technology transfer, trainings, conferences, export and import of products, etc.

Explicit and tacit knowledge can be exchanged both as knowledge transfer and knowledge spillover. The crucial distinction between knowledge transfer and knowledge spillover is that knowledge transfer is deliberate (Atkočiūnienè, Z., Miroshnychenko, O., 2019). Tacit knowledge is transferred in the process of externalization when it intentionally becomes explicit (tacit knowledge transfer). In addition, tacit 
knowledge can be transferred unintentionally as knowledge spillover in the process of interaction, e.g., when individuals work together or live close to each other.

\section{Tacit and Explicit Knowledge Spillovers}

Knowledge created by one economic agent can be used by another one without compensation or with compensation that is less than the generation costs (Jaffe, A.B., 1998). D. Grossman and E. Helpman (1991) define knowledge spillovers as following: companies can obtain information created by others with no fee charged in a market transaction; the creators of information or its current owners do not have an efficient mechanism of protection (at the legislative level) against other companies that use their information (Grossman, G., Helpman, E., 1991). Thus, knowledge spillovers occur in situations where it is possible to acquire knowledge from external sources for free or at minimal cost (Meissner, D., 2012).

Knowledge spillover can be described as the process of acquiring knowledge from external sources at no charge or with minimal compensation to the owner of such knowledge. Knowledge spillover can occur at various levels and involves gaining information and knowledge of various types. The nature of knowledge being transferred is vital for understanding the features of their spillover mechanism.

Knowledge spillovers may result from insufficient protection of intellectual property items and reverse engineering, that is why companies generating new knowledge refer to legal remedies to protect their intangible assets and make themselves safe from knowledge leakage to competitors. Knowledge spillovers can also occur in the way of the joint activities of research organizations, private and public companies.

Knowledge spillover channels are often related to economic transactions and can occur at different levels: individual (exchange of information, ideas, and knowledge between employees of various companies and organizations); interaction of legal entities (companies and organizations); international (global) level. Furthermore, knowledge spillover channels can be transparent (libraries, academic research databases, print media, participation in conferences, etc.) and have limited access status (Leahy, D., Neary, J.P., 2007).

Tacit knowledge is transferred through observation and personal communication. It can be transformed into explicit knowledge in the process of socialization and externalization. Recent research indicates that tacit knowledge spillovers are facilitated by the concentration of companies in the region or cluster where such knowledge is created. In this case, companies extract full value from such spillovers (Breschi, S., Lissoni, F., 2001). To put it in another way, fundamental knowledge has a high proportion of tacit, uncodified information. Explicit (codified) knowledge spillovers are not so dependent on geographic concentration and are relatively easy to implement, unlike tacit knowledge. 
Knowledge spillovers can be presented in different forms through differentiated channels and are not limited to a specific area of activity of a company, organization, economic sector, or field of science. The efficiency of knowledge spillovers depends on the innovative potential and the absorption capacity of a recipient and is enhanced by the interaction of geographically close entities.

V. Cohen and D. Levinthal (1991) define the absorption potential of a company as the capability to absorb knowledge, which depends on the specific experience and education of its employees (Cohen, W., Levinthal, D., 1991). A survey of 358 heads of the R\&D departments at Swiss companies showed that the company's proprietary investments in $\mathrm{R} \& \mathrm{D}$, which depend on its capability to understand and absorb the innovations of other companies, are the most efficient knowledge spillover channels (Harabi, N., 1997).

D. Meissner (2012) points out the differences between innovative and absorption potential. Innovative potential is the capability to create new knowledge and develop new technologies using R\&D and is not always tied to the capability to absorb that knowledge from external sources (Leahy, D., Neary, J.P., 2007).

\section{The R\&D spillover effects}

The spillovers help to disseminate knowledge and create spillover effects as a result of an accidental knowledge leakage and a targeted exchange of information (Breschi, S., Lissoni, F., 2001). The R\&D spillover effects are indirect effects of the R\&D outcomes spreading that shows influence of R\&D on entities, which are not involved in the creating a new knowledge. The result of spillover effects depends on the absorption potential of an organization or company, i.e., their capability to shape information flows using the total amount of information that comes from external sources.

Researchers consider forms of spillover effects as a part of externality theory (Marshall, A., 1920; Pigou, A., 1920). The term an "externality" was introduced by A. Marshall and developed by A. Pigou in 1920. There are differences between externalities and the R\&D spillovers. They are not synonymous; they are two phases of one phenomenon (Tsyplakova, D.A., 2010). The R\&D spillovers are the source of externalities; and externalities have mostly positive effect of spillovers on innovation activity. Unintended use of knowledge could result in different types of spillover effects and cause knowledge externalities (Atkočiūnienè, Z., Miroshnychenko, O., 2019). The types of the $R \& D$ spillovers have different effects on companies $R \& D$ expenditures (Bakhtiari, S., Breuning, R., 2017). Three distinct types of the R\&D spillovers have been identified in the literature: knowledge spillovers, market spillovers, and network spillovers (Jaffe, A.B., 1998; Jones, C.I., John C.W., 1998). The types of the R\&D spillovers effect on innovation diffusion and innovation development at different levels of knowledge transmission. 
Knowledge spillover effect is "considering as a beneficial effect of one economic entity on the welfare of the another one (receiving additional income), occurring outside the framework of market transactions and is not reflected in the market prices, as a consequence of production or consumption, it is generally considered that without any (or less than received benefit) direct compensation to the knowledge creator" (Tsyplakova, D.A., 2010, p. 210). Knowledge spillover effects "occur when the information collected and applied for performing a certain activity eventually creates opportunities to apply this knowledge in other areas" (Ogurtsova, E.V. et al., 2019, p. 411). The spillover enhances the development of new ideas, knowledge and new directions of their application. The R\&D activity has spillover effects on innovation development and may facilitate indirect transfer of knowledge (Ogurtsova, E.V. et al., 2019).

Most of the academic literature identifies such types of knowledge spillover effects (Marshall, A., 1920; Arrow, K.J., 1962; Romer, P.M., 1986; Griliches, Z., 1992; Kaiser, U., 2002; Tsyplakova, D.A., 2010; Meissner, D., 2012; Ramadani, V. et al. 2017), that are presented in Table 2.

Table 2: The types of Knowledge Spillover effects

\begin{tabular}{|l|l|}
\hline \multicolumn{1}{|c|}{ Classification } & \multicolumn{1}{|c|}{ Types } \\
\hline According to object of diffusion & $-\quad$ embodied or rent knowledge spillover effects \\
& $-\quad$ disembodied or pure knowledge spillover effects \\
\hline According to subject of diffusion & $-\quad$ technology push knowledge spillover effects \\
\hline According to direction of activity & $-\quad$ demand-driven knowledge spillover effects \\
\hline According to type of direction & $-\quad$ production knowledge spillover effects \\
\hline According to sours of knowledge & $-\quad$ direct knowledge spillover effects \\
\hline According to direction of diffusion & $-\quad$ indirect knowledge spillover effects \\
\hline According to level of impact & $-\quad$ intra-organization knowledge spillover effects \\
\hline According to space and time & $-\quad$ intra-industry or horizontal knowledge spillover effects \\
\hline According to application of knowledge & $-\quad$ simulation knowledge spillover effects \\
\hline According to origin & $-\quad$ adaptive knowledge spillover effects \\
\hline & $-\quad$ domestic knowledge spillover effects \\
& $-\quad$ international knowledge spillover effects \\
\hline
\end{tabular}

Source: compiled by the author

There are embodied and disembodied knowledge spillovers (Griliches, Z., 1992). Embodied spillovers or rent spillovers occur when you purchase innovative products or services. The effects of rent spillovers manifest themselves in reduced investment 
costs for creating innovative products or services of improved or cheaper technologies (Meissner, D., 2012). Disembodied knowledge spillovers or pure knowledge spillovers are the result of borrowing ideas from other entities. The effects of pure knowledge spillovers have a positive impact on fundamental and applied research conducted by both state scientific institutions and private companies.

Technology push knowledge spillover effects mean consequence from the transfer of knowledge to new areas of application. Demand-driven knowledge spillover effects deal with a demand orientation, when the result comes from the application of new knowledge from other areas in order to identify possible solutions of existing problems (Meissner, D., 2012).

Knowledge spillover effects arise not only as an output of production activity, but also in the process of consumption. For example, consumers receive additional benefits according to an increasement in consumer surplus associated with improved product quality as an issue of improved manufacturing technology. Hence, depending on direction of activity that generates knowledge spillover effects, production and consumer effects could have been distinguished (Tsyplakova, D.A., 2010).

There are direct knowledge spillover effects, when knowledge spill over by the creator to the recipient on his own initiative and does not require the involvement of third parties, while indirect knowledge spillover effects are results gained from diffusion of knowledge with the participation of one or more intermediaries. Indirect knowledge spillover effects are mostly manifested in the medium and long-term period, direct knowledge spillover effects allow entity (agent, economic unit) to quickly receive outcomes in the form of measurable added value (Meissner, D., 2012).

Using external sources of knowledge causes intra-organization knowledge spillover effects, as a result of knowledge transformation within one organization is called inter-organization knowledge spillover effects.

Inter-industry or horizontal knowledge spillover effects are the outcomes of diffusion of knowledge between entities at the same level of interaction, in the same field of activity. Intra-industry or vertical knowledge spillover effects demonstrate effective exchange of knowledge on different stages of innovation activity (between knowledge generators and knowledge consumers). Vertical knowledge spillovers have a steady positive impact on the economic performance of companies, while the effect of horizontal knowledge spillovers is usually lower (Czarnitzki, D., Kornelius K., 2007).

Private knowledge spillover effects have impact on individual business entities; social knowledge spillover effects - on all business entities, for example, social benefits caused by increasing in the level of education, intensification of scientific research activity, etc. (Döring, T., Schnellenbach, J., 2006; Tsyplakova, D.A., 2010).

Depending on the concept of innovation diffusion in time and space (Kandler, A., Steele, J., 2009), it is necessary to distinguish between time knowledge spillover effects (affecting subsequent generations) and spatial knowledge spillover effects 
(affecting economic entities located in the same economic space). Time knowledge spillover effects are generated because of the impact of the R\&D achievements, that creates opportunities to reduce costs in the future. An obvious example of this is the development of cheap technologies for the production of solar energy that will give a significant economic effect in the future (Tsyplakova, D.A., 2010). According to D.B. Audretsch, M. Keilbach (2007), A. Kandler, J. Steele (2009), P. Krugman (2010), there are spatial knowledge spillover effects, that prompts economic agents adjacent to important sources of knowledge to conduct their innovation activity at a faster pace than competing economic agents located in any other place.

The simulation knowledge spillover effects are the outcomes of direct transfer technology without any adaptation by the recipient entity; on the contrary, when new knowledge has an individual application depending on the specific situation of the recipient, we have adaptive knowledge spillover effects (Meissner, D., 2012).

Knowledge spillover effects can be of domestic and international origin (Ramadani, V. et al., 2017). Specifically, international knowledge spillover effects have place in the state scientific organizations, corporations and enable entities with the access to knowledge generated by others and gain benefits as a result of targeted investments in knowledge creation and technology development. Foreign direct investment and licensing of foreign technology are the main channels for such type of knowledge spillover effects arising.

Market spillovers effects are the benefits that arose through the activities of market forces for a new or improved product, created to be "spilled over" to consumers. It is social benefit for customers that is not captured by the innovator. Network spillover effect is the result of implementation of a new technology caused by the development of a set of related technologies. J. Medhurst et al. (2014) defined network spillover effect as "the effect of programme innovation on the development of a "critical mass" of users, where the take-up of the innovation by additional users, increases the value of the innovation to existing users (for example, computer games)".

\section{Conclusions}

Knowledge can "travel" among companies and enhance innovation development and economic growth. Nowadays, the creating a new knowledge is not mostly considered as an internal process. Economic agents can acquire new knowledge from other entities. Moreover, it can happen for free or with minimal compensation. This process of acquiring new knowledge from external sources without payment in normal market transaction is called the $R \& D$ spillovers.

The type and forms of knowledge have impact on the nature of the $R \& D$ spillovers. Spill over tacit and explicit knowledge occur at different levels. The tacit knowledge spillover is more complex and can happen mostly at individual level in the process 
of interaction. Tacit group knowledge creates routine - pattern actions, that cannot exist in isolation. The R\&D spillover effects can arise as a result of the use of explicit knowledge (documented information in paper or electronic form (documents, articles, books), or in the form of products. All the evidence suggests that such phenomena are always accompanied by tacit knowledge - information required for practical purposes and arose through an exchange of the staff, scientists and collaboration in the form of joint projects.

The main factors, that have influence on generation of the R\&D spillover effects: nature of knowledge (knowledge is non-rival and non-excludable); lack of intellectual property rights to knowledge as a resource and consumer good (the price does not reflect the cost of its alternative use); high degree of asymmetries of information about expenses and benefits, about ownership of the resource, etc. Therefore, knowledge flows are the key to innovation activity, the basis for the R\&D spillover effects and the source for economic growth, particularly in a spatially limited economic system.

\section{REFERENCES}

Arrow, K.J. (1962). Economic welfare and the allocation of resources for invention. In Nelson, R.R. (Ed.), The Rate and Direction of Inventive Activity. Princeton, NJ: Princeton University Press, 609-626

Atkočiūnienè, Z., Miroshnychenko, O. (2019). Towards sustainable development: the role of R\&D spillovers in innovation development, Journal of security and sustainability issues, 9 (2), 409-419. http://doi.org/10.9770/jssi.2019.9.2(4).

Audretsch, D.B., Keilbach, M. (2007). The theory of knowledge spillover entrepreneurship, Journal of management studies, 44(7), 1247-1254. URL: https://www.effectuation.org/wp-content/uploads/2017/06/The-Theory-of-Knowledge.pdf

Bolisani, E., Bratianu, C. (2018). Emergent Knowledge Strategies: Strategic Thinking in Knowledge Management (pp. 1-22). Cham: Springer International Publishing. http://doi.org/10.1007/978-3319-60656_1

Breschi, S., Lissoni, F. (2001). Knowledge spillovers and local innovation systems: a critical survey, Industrial and corporate change, 975-1005. http://doi.org/10.1093/icc/10.4.975

Breuning, R., Bakhtiari, S. (2017). The role of spillovers in research and development expenditure in Australian industries. URL: https://www.industry.gov.au/sites/g/files/net3906/f/May\%202018/ document/pdf/the_role_of_spillovers_in_research_and_development_expenditure_in_australian_industries.pdf

Cassiman, B., Veugelers, R. (2002.) R\&D cooperation and spillovers: some empirical evidence from Belgium, American Economic Review, 92 (4), 1169-1184. http://doi.org/ 10.1257/00028280260344704

Cohen, M.D., Burkhart, R., Dosi, D., Egidi, M., Marengo, L., Warglien, M., Winter, S. (1996). Routines and other recurring actions patterns of organizations: Contemporary research issues, Indust. Corporate Change, 5(3), 653-698

Cohen, W., Levinthal, D. (1991). Absorptive capacity: a new perspective on learning and innovation, Administrative science quarterly, 35, 128-152. http://doi.org/10.2307/2393553

Czarnitzki, D., Kornelius, K. (2007). Spillovers of Innovation Activities and their Profitability (Discussion Paper no 07-073), Mannheim: ZEW 
Davenport, T.H., Prusak, L. (1998). Working Knowledge: How Organizations Manage What They Know, Harvard Business School Press. http://doi.org/10.1145/348772.348775

Döring, T., Schnellenbach, J. (2006). What do we know about geographical knowledge spillovers and regional growth?: a survey of the literature, Regional Studies, 40, 375-395

Drucker, P.F. (1993). Post-capitalist Society, Butterworth-Heinemann. URL: http://pinguet.free.fr/ drucker93.pdf

Gamble, P.R., Blackwell, J. (2001). Knowledge Management: A State of the Art Guide, Kogan Page Publishers, London

Gaponenko, A., Orlova, T. (2008). Upravlenie znaniyami. Kak prevratit' znaniya v capital, Eksmo, Moscow

Goto, A., Suzuki, K. (1989). R\&D capital, rate of return on R\&D investment and spillover of R\&D in Japanese manufacturing industries, The review of economics and statistics, 71(4), 555-564

Griliches, Z. (1992). The search for R\&D spillovers, Scandinavian journal of economics, 94, 29-48

Grossman, G., Helpman, E. (1991). Innovation and Growth in the Global Economy, MIT Press, Cambridge, MA https://doi.org/10.1016/0167-7187(92)90023-R

Gupta, H. (2011). Management Information System (an Insight), International Book House Pvt Ltd., New Delhi

Hajric, E. (2018). Knowledge Management System and Practices. A Theoretical and Practical Guide for Knowledge Management in Your Organization URL: https://helpjuice.com/pdfs/Knowledge_ Management_A_Theoretical_And_Practical_Guide_Emil_Hajric(PDF).pdf

Harabi, N. (1997). Channels of R\&D spillovers: an empirical investigation of Swiss firms, Technovation, 17(11/12), 627-635

Jaffe, A.B. (1998). The importance of «spillovers» in the policy mission of the advanced technology program, Journal of technology transfer, 23(2), 11-19

Jones, C.I., John C.W. (1998). Measuring the social return to R\&D, Quarterly journal of economics, 113(4), 1119-1135

Kaiser, U. (2002). Measuring knowledge spillovers in manufacturing and services: an empirical assessment of alternative approaches, Research policy, 31, 125-44

Kandler, A., Steele, J. (2009). Innovation diffusion in time and space: effects of social information and of income inequality, Journal for the basic principles of diffusion theory, experiment and application, 3, 1-17. URL: https://core.ac.uk/download/pdf/226114889.pdf

Krugman, P. (2010). The new economic geography, now middle-aged. URL: https://www.princeton. edu/ pkrugman/aag.pdf

Leahy, D., Neary, J.P. (2007). Absorptive capacity, R\&D spillovers and public policy, International journal of industrial organization, 25(5), 1089-1108

Marshall, A. (1920). Principles of Economics. 8th Edition, Macmillan, London

Medhurst, J., Marsden, J., Jugnauth, F., Peacock, M., Lonsdale, J. (2014). An economic analysis of spillovers from programmes of technological innovation support. URL: https://assets.publishing. service.gov.uk/government/uploads/system/uploads/attachment_data/file/288110/bis-14-653-economic analysis-of-spillovers-from-programmes-of-technological-innovation-support.pdf

Meissner, D. (2012). Ekonomicheskie effekty «peretoka» rezultatov nauchno-tehnicheskoj i innovacionnoj deyatelnosti, Forsajt, 4, 20-31. URL: https://foresight-journal.hse.ru/data/2014/01/22/1325 743546/03-Meissner-20-31.pdf

Miroshnychenko, O. (2020). The role of knowledge spillovers in forming innovative potential, Biznes. Obrazovanie. Ekonomika: Mejdunar. nauch.-prakt. konf., Minsk, 2 aprelya 2020 g.: sb. st. V 2 ch. / redkol.: V.V. Mankevich (gl. red.) [i dr.]., Minsk, Institut biznesa BGU, CH. 2., 246-250

Nelson, P.R., Winter, S. (1982). An Evolutionary Theory of Economic Change, Cambridge, MA: Harvard University Press 
Nonaka, I.A. (1994). Dynamic theory of organizational knowledge creation, Organization science, $5(1), 14-37$

Nonaka, I., Takeuchi, H. (1995). The Knowledge-Creating Company: How Japanese Companies Create the Dynamics of Innovation, Oxford University Press, New York

Nonaka, I., Takeuchi, H., (1996). The theory of organizational knowledge creation, International Journal of Technology Management, 11 (7/8), 833-845

Ogurtsova, E.V., Tugusheva, R.R., Firsova, A.A. (2019). Innovation spillover effects of information and communications technology in higher education, Perspectives of science and education, 6(42), 409-421. http://doi.org/ 10.32744/pse.2019.6.34

Pigou, A.C. (1920). The Economics of Welfare. URL: http://oll.libertyfund.org/EBooks/Pigou_0316. pdf

Polanyi, M. (1966). The Tacit Dimension, Routledge \& Kegan Paul, London

Schumpeter, J. (1934). The Theory of Economic Development. Leipzig: Duncker and Humblot. Translated by R. Opie, Cambridg, Harvard University Press

Tsyplakova, D.A. (2010). Vneshnie effekty znanij kak ob`ektivnaya predposylka formirovaniya ekonomiki znanij, Ekonomicheskie nauki, 9(70), 45-48

Ramadani, V., Abazi-Alili, H., Dana, L.P., Rexhepi, G., Ibraimi, S. (2017). The impact of knowledge spillovers and innovation on firm-performance: findings from the Balkans countries, International entrepreneurship and management journal, 13, 299-325. https://doi.org/10.1007/s11365-016-0393-8

Romer, P.M. (1986). Increasing returns and long-run growth, Journal of political economy, 94, 10021037

Wellman, J.M. (2009). Organizational Learning. How Companies and Institutions Manage and Apply Knowledge, Palgrave Macmillan, New York. https://doi.org/10.1057/9780230621541 